\title{
PIK3CA Gene Alteration Positive
}

National Cancer Institute

\section{Source}

National Cancer Institute. PIK3CA Gene Alteration Positive. NCI Thesaurus. Code C153393.

An indication that mutation, overexpression, fusion or rearrangement involving the PIK3CA gene has been detected in a sample. 